\title{
Fetal microchimerism in a pregnant woman and risk of autoimmune disease
}

\section{Mikrochimeryzm płodowy u kobiety w ciąży a ryzyko wystąpienia choroby autoimmunologicznej}

Karolina Hadasik, Beata Bergler-Czop, Ligia Brzezińska-Wcisło

Department of Dermatology, School of Medicine, Medical University of Silesia, Katowice, Poland

Katedra i Klinika Dermatologii, Wydział Lekarski Śląskiego Uniwersytetu Medycznego w Katowicach, Polska

CORRESPONDING AUTHOR/ ADRES DO KORESPONDENCJI: dr hab. n. med. Beata Bergler-Czop Katedra i Klinika Dermatologii Wydział Lekarski

Śląski Uniwersytet Medyczny ul. Francuska 20/24

40-027 Katowice, Polska tel.: +48501352033 e-mail: bettina2@tlen.pl

\section{ABSTRACT}

Autoimmune diseases most commonly affect women in their reproductive age. Many studies have attempted to link microchimeric fetal cells with the onset of autoimmune diseases after pregnancy. One of these diseases is localized scleroderma (morphea), which is a rare fibrosing disorder of the skin and underlying tissues. The etiology of morphea is unknown, but there are some predisposing factors that may induce morphea-like lesions. We present a rare case of a patient whose first cutaneous sclerotic lesions appeared in her $35^{\text {th }}$ week of pregnancy. To our knowledge, to date pregnancy has not been treated as a predisposing factor for that disease, although it may be a risk factor, considering the phenomenon of fetal-maternal microchimerism.

\section{STRESZCZENIE}

Choroby autoimmunologiczne najczęściej dotyczą kobiet w wieku rozrodczym. W licznych badaniach na przestrzeni wielu lat analizowano potencjalną zależność między mikrochimeryzmem płodowym i rozwojem chorób autoimmunologicznych po okresie ciąży. Jednym z takich schorzeń jest twardzina ograniczona (morphea) - rzadka choroba powodująca włóknienie skóry i tkanki podskórnej. Jej etiologia jest nieznana, jednak istnieją pewne czynniki predysponujące do powstawania zmian twardzinopodobnych. Przedstawiamy rzadki przypadek pacjentki, $\mathrm{u}$ której pierwsze zmiany $\mathrm{w}$ przebiegu twardziny ograniczonej pojawiły się w 35. tygodniu ciąży. Według naszej wiedzy ciąża nie była dotychczas traktowana jako czynnik predysponujący do rozwoju tego schorzenia, choć z uwagi na zjawisko mikrochimeryzmu płodowo-matczynego może być traktowana jako czynnik ryzyka.

Key words: microchimerism, pregnancy, autoimmune disease, localized scleroderma.

Słowa kluczowe: mikrochimeryzm, ciąża, choroba autoimmunologiczna, twardzina ograniczona. 


\section{INTRODUCTION}

Autoimmune diseases (AID) include more than 70 different disorders. They are more common among women, especially in the first few years following pregnancy. These diseases include systemic lupus erythematosus, autoimmune thyroid disease, systemic sclerosis, rheumatoid arthritis, multiple sclerosis and many more. Due to the association between pregnancy and AID and the prevalence of those diseases in women, for many years studies have attempted to link fetal microchimerism (MC) with the onset of AID after pregnancy [1].

The first report that emphasized the connection between fetal MC and human disease was written by Nelson et al., who speculated that MC might be the underlying basis for higher prevalence of AID in women. The hypothesis is supported by the clinical and histopathological similarities between chronic graft versus host disease (GVHD) and morphea or systemic sclerosis, the prevalence of these in women, especially after the reproductive period, and the fact that GVHD increases with human leukocyte antigen (HLA) incompatibility of the donor [2-4].

Localized scleroderma (morphea) is a rare fibrosing disorder of the skin and underlying tissues. It is characterized by circumscribed sclerotic plaque with an ivory-colored center in the active state, with violaceous borders. With further progression, the center becomes white or yellow. Most commonly, the lesions are single or few in number, but they may be multiple and typically localized on the trunk and extremities.

The etiology of morphea is unknown, but there are some predisposing factors that may induce morphea-like lesions: trauma, radiation, medications, infection, autoimmunity, MC [1].

\section{OBJECTIVE}

This is a presentation of a rare case of a patient whose first cutaneous sclerotic lesions appeared in her $35^{\text {th }}$ week of pregnancy. To our knowledge, to date pregnancy has not been treated as a predisposing factor for that disease, although it may be a risk factor, considering the phenomenon of fetal-maternal MC.

\section{CASE REPORT}

In a 27-year-old patient, the first cutaneous sclerotic lesions appeared in the $35^{\text {th }}$ week of her second pregnancy. Initially they were localized within the right foot, then on the right thigh. Consecutive multiple sclerotic lesions appeared 6 months after delivery within the middle abdomen and the right

\section{WPROWADZENIE}

Grupa chorób autoimmunologicznych (autoimmune diseases - AID) obejmuje ponad 70 różnych jednostek chorobowych. Schorzenia te częściej występują u kobiet, zwłaszcza w okresie kilku lat po ciąży. Do AID należą m.in.: toczeń rumieniowaty układowy, autoimmunologiczna choroba tarczycy, twardzina układowa, reumatoidalne zapalenie stawów i stwardnienie rozsiane. Ze względu na zależność między ciążą a AID oraz powszechne występowanie tych chorób u kobiet już od wielu lat prowadzone są badania nad związkiem między mikrochimeryzmem płodowym (microchimerism - MC) i występowaniem AID po ciąży [1].

Pierwsze doniesienia wskazujące na zależność między MC i chorobami występującymi u ludzi przedstawili Nelson i wsp. Postawili oni hipotezę, że MC może odpowiadać za zwiększoną częstość występowania AID u kobiet. Na jej słuszność mogą wskazywać podobieństwa w obrazie klinicznym i histopatologicznym między przewlekłą chorobą przeszczep przeciwko gospodarzowi (graft versus host disease - GVHD) i morphea lub twardziną układową, częste występowanie tych chorób u kobiet, zwłaszcza po okresie reprodukcyjnym, a także wzrost ryzyka wystąpienia GVDH towarzyszący niezgodności HLA dawcy [2-4].

Twardzina ograniczona (morphea) jest rzadką chorobą powodującą włóknienie skóry i tkanek podskórnych. W stanie aktywnym charakteryzuje się powstawaniem na skórze ograniczonych, stwardniałych ognisk o barwie kości słoniowej, otoczonych sinofioletową obwódką. Wraz z rozwojem choroby środek zmian przybiera barwę białą lub żółtą. Najczęściej ogniska są pojedyncze lub nieliczne, mogą jednak być również mnogie. Zazwyczaj zmiany są umiejscowione na tułowiu i kończynach.

Etiologia twardziny ograniczonej nie jest znana, jednak istnieje pewna grupa czynników, które mogą wywoływać zmiany o typie morphea. Należą do nich: uraz, promieniowanie, leki, zakażenie, reakcje autoimmunologiczne, MC [1].

\section{CEL PRACY}

W pracy przedstawiamy rzadki przypadek pacjentki, u której pierwsze twardzinowe zmiany skórne wystąpiły w 35. tygodniu ciąży. Według naszej wiedzy ciąża nie była dotychczas traktowana jako czynnik predysponujący do rozwoju tego schorzenia, choć uwzględniając zjawisko MC, może być traktowana jako czynnik ryzyka.

\section{OPIS PRZYPADKU}

U 27-letniej pacjentki pierwsze twardzinowe zmiany skórne wystąpiły w 35. tygodniu drugiej ciąży. Początkowo były umiejscowione na prawej stopie, a następnie na prawym udzie. Kolejne liczne zmiany 
knee. Initially, within the lesions, the patient felt increased warmth of the skin, and with time the mobility in the ankle joint became limited, greatly hampering dorsiflexion, plantar flexion, and mobility in the metatarsophalangeal joints.

In 2014, 6 months after delivery, the patient was admitted to the Department of Dermatology, Medical University of Silesia, due to significant progression of skin lesions. Apart from caesarean section performed twice (abnormal positioning of the fetus) and operational left elbow reconstruction after childhood trauma, the patient's medical history revealed no susceptibility. The patient denied a family history of connective tissue diseases or other autoimmune diseases.

At the time of the admission, lesions were observed in the left middle abdomen area, on the right thigh, on the right knee and on the dorsal surface of the right foot. All lesions were evidently separated from the healthy skin and exhibited increased consistency: they were hardened, of brown-yellowish hue, shiny, with increased warmth in relation to the surrounding skin. Moreover, a number of stretch marks were visible on the abdominal skin. The peripheral lymph nodes were not enlarged. The mucous membranes and nail plates were free of lesions (figs. 1-3). twardzinowe pojawiły się na skórze środkowej części brzucha i prawego kolana po 6 miesiącach od porodu. Początkowo pacjentka odczuwała podwyższona ciepłotę skóry w obrębie zmian. Następnie doszło do ograniczenia ruchomości stawu skokowego ze znacznym utrudnieniem zginania grzbietowego i podeszwowego stopy oraz zmniejszonej ruchomości stawów śródstopno-paliczkowych.

W 2014 r., 6 miesięcy po porodzie, pacjentka została przyjęta do Kliniki Dermatologii Śląskiego Uniwersytetu Medycznego z powodu znacznego nasilenia zmian skórnych. W wywiadzie lekarskim nie stwierdzono żadnych obciążeń poza dwukrotnym cięciem cesarskim wykonanym ze względu na nieprawidłowe ułożenie płodu oraz operacyjną rekonstrukcję stawu łokciowego po urazie w dzieciństwie. Według pacjentki w wywiadzie rodzinnym nie występowały choroby tkanki łącznej ani inne choroby o podłożu autoimmunologicznym.

Przy przyjęciu zmiany chorobowe stwierdzono na skórze środkowej części brzucha po lewej stronie, na prawym udzie, prawym kolanie i powierzchni grzbietowej prawej stopy. Wszystkie zmiany były wyraźnie oddzielone od zdrowej skóry i wykazywały wzmożoną spoistość. Skóra w obrębie zmian była stwardniała, o barwie brązowo-żółtawej, lśniąca, o podwyższonej ciepłocie w stosunku do otoczenia. Na skórze brzucha

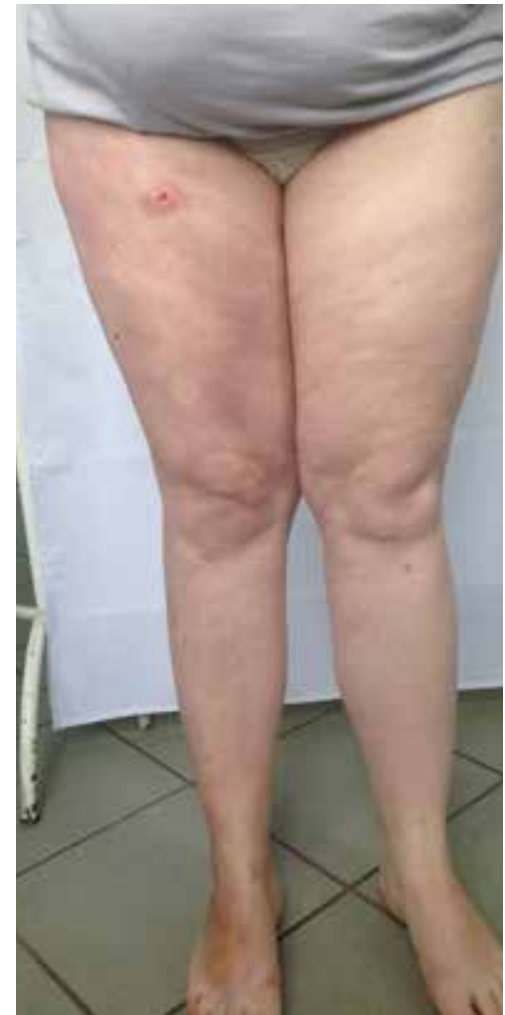

Figure I. The difference between the healthy and the morphea affected limb

Rycina I. Różnica między kończyną zdrowq a zajęta przez twardzinę ograniczonq

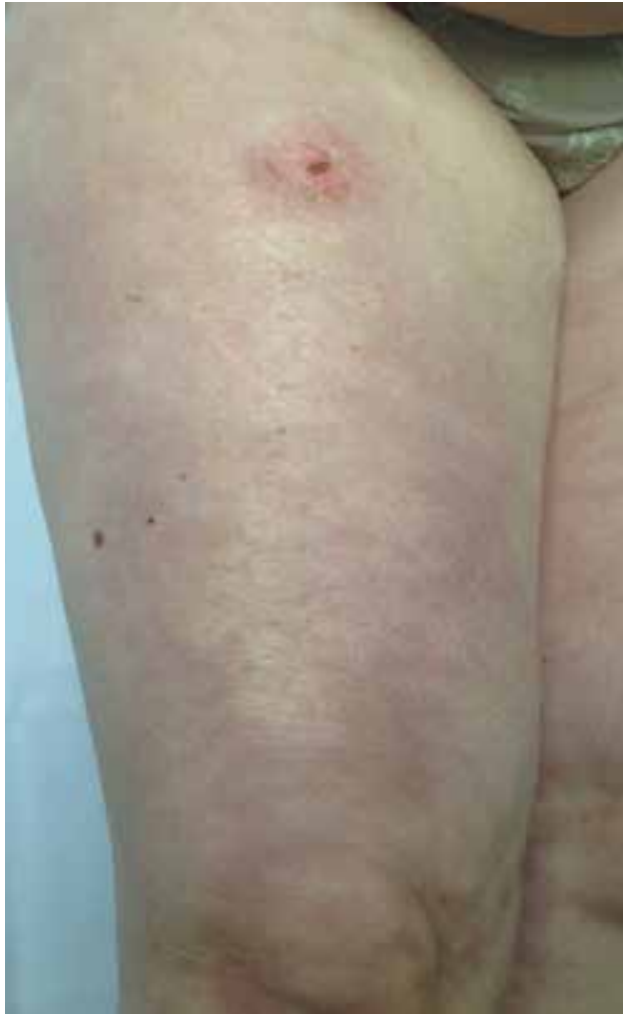

Figure 2. Lesion located on the lower limb - with mark after biopsy

Rycina 2. Zmiana umiejscowiona na kończynie dolnejwidoczny ślad po biopsji

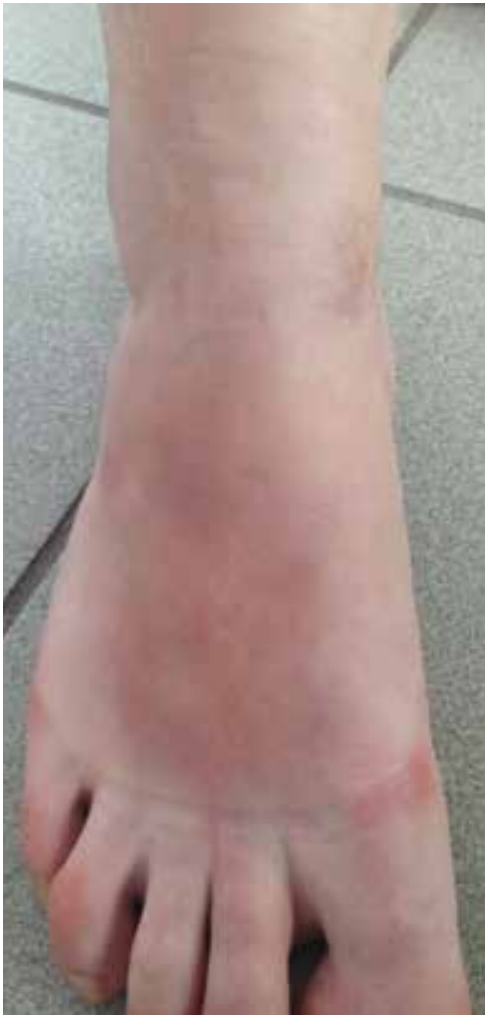

Figure 3. Lesion on dorsal site of the right foot

Rycina 3. Zmiana na powierzchni grzbietowej prawej stopy 
Laboratory studies - erythrocyte sedimentation rate (ESR), blood cell count with peripheral blood smear, iron levels, electrolytes, aspartate aminotransferase (AST), alanine aminotransferase (ALT), $\gamma$-glutamyltransferase (GGTP), bilirubin, creatinine, urea, protein, protein electrophoresis, creatinine phosphokinase (CPK), aldolase, triglycerides, cholesterol, joint reactions (Latex-R, Waaler-Rose test), general urinalysis, glucose levels - were normal.

Chest X-ray and seriogram of the upper gastrointestinal tract did not show pathology. Mycological examination (direct preparation and culture - middle abdominal area and feet) - negative. Capillaroscopy - normal picture. Borrelia burgdorferi IgG and IgM antibodies - negative.

Histopathological examination (lower limb) showed the lack of skin appendages and averagely intense lymphocytic inflammatory infiltration around the vessels, which confirmed the initial clinical diagnosis.

The indirect immunofluorescence on Hep2 cells/monkey esophagus mosaic revealed IgG antinuclear antibodies (ANA) at a titer of $1: 5120$ in a homogeneous and speckled pattern.

Currently, the patient is taking vitamin E 0.4 $1 \times 1$ capsules; skin lesions are not progressing. A follow-up test of ANA2, performed 3 months after hospitalization, detected antinuclear antibodies of a titer of 1/640 in a homogeneous pattern. Currently, the patient is under continuous care at the outpatient clinic of dermatology.

\section{DISCUSSION}

Trafficking of fetal cells into the maternal circulation begins very early in the pregnancy and its effects are long-lasting. The mechanism of transplacental cell trafficking involves vascular endothelial growth factor and integrin-dependent pathways, but the molecular signals that initiate the process are unknown [1]. All types of fetal cells, including stem cells, cross the placenta during normal pregnancy to enter the maternal blood and tissues, where they may be located decades after pregnancy. Factors predisposing to the development of fetal MC are much debated. There is more fetomaternal cell trafficking, where the placenta is abnormal and in certain complications of pregnancy, such as fetal aneuploidy, pregnancy loss and pre-eclampsia or fetal surgery [2-4].

Fetal cell penetration into the maternal circulation is an interesting phenomenon observed in pregnancy. The immune footprint in the form of MC induced by primary fetal stem cells (SCs) can be recognized until the end of the mother's stwierdzono także liczne rozstępy. Węzły chłonne obwodowe były niepowiększone. Błony śluzowe i płytki paznokciowe były wolne od zmian chorobowych (ryc. 1-3).

Wyniki badań laboratoryjnych - odczyn Biernackiego (OB), morfologia krwi z rozmazem, żelazo, elektrolity, aminotransferaza asparaginianowa (AST), aminotransferaza alaninowa (ALT), $\gamma$-glutamylotransferaza (GGTP), bilirubina, kreatynina, mocznik, białko, proteinogram, kinaza kreatynowa $(\mathrm{CPK})$, aldolaza, trójglicerydy, cholesterol, odczyn stawowy (Latex-R, odczyn Waalera-Rosego), badanie ogólne moczu i stężenie glukozy - mieściły się w granicach normy.

Nie stwierdzono również odchyleń w badaniu RTG klatki piersiowej oraz w seriogramie górnego odcinka przewodu pokarmowego. Badanie mykologiczne (preparat bezpośredni i posiew - środkowa część brzucha oraz stopy) dało wynik ujemny. Prawidłowy był również obraz kapilaroskopowy. Badanie w kierunku przeciwciał IgM/IgG przeciwko Borrelia burgdorferi dało wynik ujemny.

W badaniu histopatologicznym (kończyna dolna) stwierdzono brak przydatków skóry oraz średnio nasilony limfocytarny naciek zapalny wokół naczyń, co potwierdza wstępne rozpoznanie kliniczne.

Metodą immunofluorescencji pośredniej z wykorzystaniem mozaiki komórek HEp-2/przełyku małpy wykazano obecność przeciwciał przeciwjądrowych (ANA) IgG w mianie 1 : 5120, o typie świecenia homogenno-plamistym.

Aktualnie pacjentka przyjmuje witaminę E 0,4 g $1 \times 1$ kaps. dziennie. Nie obserwuje się rozwoju zmian skórnych. W kontrolnym oznaczeniu przeciwciał ANA2 wykonanym 3 miesiące po hospitalizacji wykryto przeciwciała przeciwjądrowe w mianie 1/640, o typie homogennym. Pacjentka jest objęta specjalistyczną opieką w poradni dermatologicznej.

\section{OMÓWIENIE}

Migracja komórek płodu do krwiobiegu matki następuje na bardzo wczesnym etapie ciąży, a proces ten ma długotrwałe skutki. W mechanizmie przezłożyskowego przenoszenia komórek uczestniczy czynnik wzrostu śródbłonka naczyniowego i ścieżki sygnałowe zależne od integryn, jednak sygnały molekularne, które inicjują ten proces, nie zostały dotychczas poznane [1]. Wszystkie typy komórek płodowych, w tym komórki macierzyste, podczas prawidłowej ciąży przechodzą przez łożysko. Przenikają do krwiobiegu i tkanek matki, gdzie mogą się znajdować nawet kilkadziesiąt lat po porodzie. Czynniki predysponujące do rozwoju MC płodowego są przedmiotem wielu dyskusji. Wiadomo, że wzmożona migracja komórek między płodem a matką następuje, gdy łożysko funkcjonuje nieprawidłowo oraz w przypadku niektórych 
ontogenesis. The majority of available data postulate the presence of a multi-organ repair effect in degenerative maternal cells induced by the analyzed phenomenon. For example, fetal SCs enter the mother's circulation and differentiate into mature thyroid follicular cells. It has been proven that SCs of the fetus permeate into the mother's thyroid adenoma in order to combat the disease $[1,2]$. Many studies shared the presence of fetal $\mathrm{MC}$ in autoimmune thyroid inflammation. A greater frequency of male DNA has been found in thyroid tissue of women with Hashimoto's disease compared to nodular goiter, but also in Graves disease compared to controls with adenoma [1-3]. Similar observations were made in the case of hepatitis C. Stem cells have the capacity to respond to signals generated by the pathologically altered tissues; then they migrate into the affected areas and replace the necrotic tissues or act as protectors by the secretion of specific protective agents, which suggests that they may have an unrivaled therapeutic potential in perinatal medicine [1, 2]. In contrast, Rygaard et al. believe that the high incidence of autoimmune aggressive diseases observed in women is also associated with fetal microchimerism [5]. The literature presents many confirmations of a relationship between fetalmaternal MC and AID. In a cohort study Jeanty et al. divided women into the following groups: 1) women who had no previous pregnancy; 2) women who had a vaginal delivery; 3) women who had a cesarean section (CS); and 4) women who had an abortion. The study involved more than one million women. Overall, the risk of AID in women was significantly higher in the first year following vaginal delivery or CS, but was lower in the first year following abortion. While the risk of AID was reduced between the $3^{\text {rd }}$ and $10^{\text {th }}$ year following vaginal delivery, there was no evidence of a change in the risk of AID beyond the first year following CS or abortion. However, women who were pregnant had a higher incidence of AID than those who had no pregnancy records [6].

Initially, research on fetal MC occurring in AID focused on systemic sclerosis (SSc) due to the clinical similarity to GVHD. Studies by Nelson et al. confirmed that women with systemic sclerosis have significantly elevated levels of male DNA in comparison with healthy women, but these levels were similar to those of the pregnant women with a normal male fetus [7]. Similar conclusions were reached by Artlett et al. In their study, women with systemic sclerosis had high levels of fetal DNA both in the peripheral blood and in skin lesions [8].

Van Wyk et al. in a case controlled study took note that preeclampsia and other pregnancy com- powikłań ciąży, takich jak aneuploidia u płodu, utrata ciąży, stan przedrzucawkowy lub zabieg chirurgiczny u płodu [2-4].

Przenikanie komórek płodowych do krwiobiegu matki jest interesującym zjawiskiem obserwowanym podczas ciąży. Ślad immunologiczny w postaci MC wywoływanego przez pierwotne komórki macierzyste płodu jest wykrywalny aż do końca ontogenezy matki. Większość danych wskazuje na wielonarządowy efekt naprawczy w komórkach zwyrodnieniowych matki indukowany przez analizowane zjawisko. Na przykład, komórki macierzyste płodu przedostają się do krwiobiegu matki i różnicują w dojrzałe komórki pęcherzykowe tarczycy. Potwierdzono, że płodowe komórki macierzyste przenikają do gruczolaka tarczycy matki w celu zwalczania choroby [1, 2]. W licznych badaniach donoszono o obecności płodowych komórek macierzystych w przebiegu autoimmunologicznego zapalenia tarczycy. Wzmożoną obecność męskiego DNA stwierdzono $\mathrm{w}$ tkance tarczycy u kobiet $\mathrm{z}$ chorobą Hashimoto w porównaniu z wolami guzkowymi, a także w chorobie Gravesa-Basedowa w porównaniu z grupa kontrolną z gruczolakiem [1-3]. Podobną prawidłowość obserwowano w przypadku wirusowego zapalenia wątroby typu C. Komórki macierzyste mają zdolność reagowania na sygnały generowane przez zmienione chorobowo tkanki. Migrują wówczas do zajętych obszarów i zastępują tkanki martwicze lub działają protekcyjnie poprzez wydzielanie swoistych czynników ochronnych. Obserwacje te wskazują na ogromny potencjał terapeutyczny komórek macierzystych w medycynie perinatalnej [1, 2]. Rygaard i wsp. twierdzą natomiast, że z MC płodowo-matczynym wiąże się duża częstość występowania chorób mających podłoże $\mathrm{W}$ agresji autoimmunologicznej [5]. W piśmiennictwie można znaleźć liczne doniesienia potwierdzające zależność między MC płodowo-matczynym i występowaniem AID. W badaniu kohortowym Jeanty i wsp. uczestniczki podzielono na następujące grupy: 1) kobiety, które nigdy nie były w ciąży; 2) kobiety, które rodziły drogą pochwową; 3) kobiety, które przeszły zabieg cesarskiego cięcia (CC) oraz 4) kobiety po przedwczesnym zakończeniu ciąży. W badaniu wzięło udział łącznie ponad milion kobiet. Zaobserwowano, że ryzyko wystąpienia AID u kobiet jest istotnie wyższe w pierwszym roku po porodzie drogą pochwową lub przez CC, natomiast jest niższe w pierwszym roku po przedwczesnym zakończeniu ciąży. Choć ryzyko wystąpienia AID było mniejsze między 3. a 10. rokiem po porodzie drogą pochwową, nie stwierdzono zmian w ryzyku wystąpienia AID po upływie pierwszego roku od porodu przez CC lub przedwczesnego zakończenia ciąży. Zaobserwowano jednak zwiększoną częstość występowania AID u kobiet z ciążą w wywiadzie niż u kobiet, które nie były w ciąży [6]. 
plications, such as miscarriage and intra-uterine growth restriction (IUGR), could be associated with increased levels of fetal cell trafficking, and suggested that women with these pregnancy complications would be at greater risk of later scleroderma development. Statistically, in 103 women who subsequently developed SSc compared to healthy controls, they found that the incidence of hypertension in the pregnancy history or the incidence of IUGR fetus was significantly higher [9].

However, the theory of fetal MC in SSc was not confirmed in the study by Russo et al. The retrospective analysis covered 387 patients with systemic scleroderma and 367 healthy individuals. The authors excluded birth order, family size, parity, age at first pregnancy and the gender of the first child as relevant factors in the understanding of epidemiology and the pathogenesis of SSc, although they admitted that a larger study with a well-matched control population is required [10].

Microchimerism has been investigated with different methods for more than 30 years. Kekow et al. analyzed the occurrence of the phenomenon in 142 women; 72 of them suffered from rheumatoid arthritis; 16 had systemic lupus erythematosus, while the remaining 54 were healthy women. All patients were tested for the occurrence of the TSPY1 gene in the peripheral blood. The data indicated long persistence of $\mathrm{MC}$ as a potential marker of pathologic clearance of semi-allogeneic DNA in rheumatic diseases without the effects on disease onset or status. Microchimerism could also be an epiphenomenon of autoimmunity and therapy without having an effect on the clinical manifestation and the phenotype of rheumatoid arthritis and systemic lupus erythematosus [11].

The role of MC was also repeatedly tested for childhood AID. Maternal cells were often detected in the tissue of the myocardium in patients with neonatal lupus syndrome, in the blood and pancreas of patients with type 1 diabetes in the blood and muscles of patients with dermatomyositis and other AID [12].

\section{CONCLUSIONS}

We have presented the first reported case of a pregnant patient where we may suspect the role of MC as a potential etiological factor for the development of morphea. Previous reports only related to the development of systemic AID. The patient remains under our supervision due to the presence of immunological markers (ANA) and the possible risk of development of SSc.
Badania nad wpływem MC płodowego na AID koncentrowały się początkowo na twardzinie układowej (systemic sclerosis - SSc) ze względu na jej podobieństwo kliniczne do GVHD. W pracach Nelsona i wsp. wykazano, że kobiety z SSc mają istotnie podwyższony poziom męskiego DNA w porównaniu z kobietami zdrowymi, jednak jest on zbliżony do poziomu u kobiet w ciąży z prawidłowo rozwijającym się płodem męskim [7]. Do podobnych wniosków doszli Artlett i wsp. W przepro-wadzonym przez nich badaniu u kobiet z SSc stwierdzono wysoki poziom DNA płodowego zarówno w krwi obwodowej, jak i w zmianach skórnych [8].

W badaniu kliniczno-kontrolnym Van Wyk i wsp. wskazali na związek między stanem przedrzucawkowym i innymi powikłaniami ciąży, takimi jak poronienie i wewnątrzmaciczne zahamowanie wzrostu płodu (intra-uterine growth restriction - IUGR), i nasileniem migracji komórek płodowych. Zasugerowali również, że kobiety z powyższymi powikłaniami ciążowymi mają zwiększone ryzyko późniejszego wystąpienia SSc. Analiza statystyczna 103 kobiet, u których w późniejszym okresie pojawiła się SSc, w porównaniu ze zdrową grupą kontrolną wykazała istotnie wyższą częstość występowania nadciśnienia w wywiadzie ciążowym lub IUGR [9].

Teorii wpływu MC płodowego na rozwój SSc nie potwierdzono w badaniu Russo i wsp. Retrospektywną analizą objęto 387 pacjentek z SSc oraz 367 zdrowych kobiet. Badacze wykluczyli kolejność urodzenia, wielkość rodziny, liczbę ciąż, wiek pierwszej ciąży oraz płeć pierwszego dziecka jako czynniki istotne w epidemiologii i patogenezie SSc, zaznaczając jednocześnie, że niezbędne jest przeprowadzenie większego badania z dobrze dobraną grupą kontrolną [10].

Mikrochimeryzm jest badany przy zastosowaniu różnych metod już od ponad 30 lat. Kekow i wsp. analizowali występowanie tego zjawiska w grupie 142 kobiet: 54 zdrowych, 72 z reumatoidalnym zapaleniem stawów i 16 z toczniem rumieniowatym układowym. Wszystkie pacjentki zostały poddane badaniu w kierunku obecności genu TSPY1 w krwi obwodowej. Dane pokazały, że długie utrzymywanie się MC jest potencjalnym markerem nieprawidłowego usuwania semiallogenicznego DNA w chorobach reumatycznych - bez wpływu na czas wystąpienia i stan choroby. Mikrochimeryzm może również stanowić epifenomen reakcji autoimmunologicznej i stosowanego leczenia, nie wpływając na obraz kliniczny i fenotyp reumatoidalnego zapalenia stawów i tocznia rumieniowatego układowego [11].

Rolę MC analizowano także wielokrotnie w zakresie AID w dzieciństwie. Komórki matki często wykrywano w tkance mięśnia sercowego u chorych z noworodkowym zespołem tocznia, we krwi i trzustce pacjentów z cukrzycą typu 1, we krwi i mięśniach pacjentów z zapaleniem skórno-mięśniowym i innymi AID [12]. 


\section{CONFLICT OF INTEREST}

The authors declare no conflict of interest.

\section{WNIOSKI}

W niniejszej pracy opisano pierwszy przypadek pacjentki w ciąży, w którym można podejrzewać wpływ MC jako potencjalnego czynnika etiologicznego warunkującego wystąpienie morphea. Wcześniejsze doniesienia dotyczyły wyłącznie rozwoju układowych AID. Pacjentka jest pod naszą opieką ze względu na obecność markerów immunologicznych (ANA) oraz ryzyko rozwoju SSc.

\section{KONFLIKT INTERESÓW}

Autorzy nie zgłaszają konfliktu interesów.

\section{References}

Piśmiennictwo

1. Khashan A.S., Kenny L.C., Laursen T.M., Mahmood U., Mortensen P.B., Henriksen T.B., et al.: Pregnancy and the risk of autoimmune disease. PLoS One 2011, 6, e19658.

2. Nelson J.L., Furst D.E., Maloney S., Gooley T., Evans P.C., Smith A., et al.: Microchimerism and HLA-compatible relationships of pregnancy in scleroderma. Lancet 1998, 351, 559-562.

3. Nelson J.L.: Microchimerism and the pathogenesis of systemic sclerosis. Curr Opin Rheumatol 1998, 10, 564-571.

4. Miech R.P.: The role of fetal microchimerism in autoimmune disease. Int J Clin Exp Med 2010, 3, 164-168.

5. Rygaard K., Lindenberg S.: Stem cells for obstetricians and gynecologists. Acta Obstet Gynecol Scand 2002, 81, 383-388.

6. Jeanty C., Derderian S.C., Mackenzie T.C.: Maternal-fetal cellular trafficking: clinical implications and consequences. Curr Opin Pediatr 2014, 26, 377-382.

7. Nelson J.L., Gillespie K.M., Lambert N.C., Stevens A.M., Loubiere L.S., Rutledge J.C., et al.: Maternal microchimerism in peripheral blood in type 1 diabetes and pancreatic islet beta cell microchimerism. Proc Natl Acad Sci USA 2007, 104, 1637-1642.

8. Artlett C.M., Smith J.B., Jimenez S.A.: Identification of fetal DNA and cells in skin lesions in women with systemic sclerosis. N Engl J Med 1998, 338, 1186-1191.

9. Van Wyk L., van der Marel J., Schuerwegh A.J., Schouffoer A.A., Voskuyl A.E., Huizinga T.W., et al.: Increased incidence of pregnancy complications in women who later develop scleroderma: a case control study. Arthritis Res Ther 2011, 13, R183.

10. Russo P.A., Lester S., Roberts-Thomson P.J.: Systemic sclerosis, birth order and parity. Int J Rheum Dis 2014, 17, 557-561.

11. Kekow M., Barleben M., Drynda S., Jakubiczka S., Kekow J., Brune T.: Long-term persistence and effects of fetal microchimerisms on disease onset and status in a cohort of women with rheumatoid arthritis and systemic lupus erythematosus. BMC Musculoskelet Disord 2014, 14, 325.

12. Reed A.M., Picornell Y.J., Harwood A., Kredich D.W.: Chimerism in children with juvenile dermatomyositis. Lancet 2000, 356, 2156-2157.

Received: 30.10 .2017

Accepted: 27.02 .2018

Otrzymano: $30.10 .2017 \mathrm{r}$.

Zaakceptowano: $27.02 .2018 \mathrm{r}$. 